\title{
Infant Mortality in Germany in the 19th Century
}

\section{Rolf Gehrmann*}

\begin{abstract}
Developments in infant mortality in Germany have previously only been documented in a fragmentary fashion for the 19th century as a whole, and only on a small scale for the period prior to 1871. For the first time, this paper lays a solid statistical foundation by reprocessing the figures assembled by the German states of that time. The reconstructed national statistical series (from 1826 onwards) reveals a comparatively high infant mortality, with minor deviations until the turn of the 20th century. The impact of urbanisation and industrialisation is not denied, but an evaluation of the different regional patterns and trends leads to a new weighting. The living and working conditions in the countryside were thus highly determining. The relationship between fertility and infant mortality is assessed differently for the era of the sustained reduction in fertility than for the preceding period. All in all, the prevalent customs and attitudes are regarded as being vital to infants' survival chances. We therefore need to look at attitudes among the educated public and the authorities. Efforts on the part of these groups to bring about change were particularly observed in the South West, where an awareness of the dramatic problem arose comparatively early. Further historic research at the regional level will be needed in order to achieve a final evaluation of these processes.
\end{abstract}

Keywords: Infant mortality · Germany · 19 th century · Female labour · Urbanisation · Public intervention

In collaboration with Rembrandt Scholz (Max Planck Institute for Demographic Research, Rostock), it is thanks to his initiative that this paper was drafted. I am also grateful to the reviewers of Comparative Population Studies for their helpful comments. 


\section{Introduction}

Since its resurgence in the 1960s, historical demography has always focused strongly on infant mortality. Mortality research absolutely must focus on what happened to small children, given that this made a major contribution towards general developments in life expectancy. Moreover, this provides many different approaches on which further conclusions can be based. There are good reasons today why mortality in the first year of life is regarded as an important indicator of a society's state of development. As early as in the last third of the 19th century, bad chances of survival were no longer accepted as being a matter of course but were increasingly recognised as a social problem, so that the topic was the subject of studies which remain valid to the present day. These studies identified many of the factors that ever since played an important role in the analysis of the circumstances in which infants live, that is hygiene, food, female labour, living conditions and climatic conditions. Studies that were performed in this period are also of significant value since the proximity to the studied circumstances permitted insights to contemporary researchers that can nowadays only be obtained indirectly. Therefore the literature of that time is valuable as a source per se. Around the turn of the 20th century statistical methods were increasingly used, and their developed forms are still dominating research. Largely owing to the use of regression analyses, considerable progress has been made towards further delimitation of quantifiable influencing factors, such as fertility. The reconstruction of time series on infant mortality in the area of the later German Reich can help to improve the foundations on which such analyses are based. However, it is not possible to quantify all aspects of the living conditions, so that the limits of the quantifying approach should not be overlooked and the socalled qualitative sources should be kept in mind.

\section{The state of the research}

Out of the large selection of individual contributions that occasionally also appear in edited volumes and special issues of relevant journals (Bengtsson/Lundh 1994; Corsini/Viazzo 1997; Gehrmann 2002), when making an international comparison it is necessary to underline those studies where a statistical evaluation goes handin-hand with a precise knowledge of the concrete historic environment. These are naturally case studies on a sufficiently large area from which more general conclusions can be drawn. On the basis of such a study on an Icelandic island, for instance, Guttormsson and Gardarsdottir (2000) reached the conclusion that health policy, in this case in the shape of improvements in natal care, was already able to lead to a significant reduction in infant mortality around the mid-19th century, even in an area where breastfeeding was not the norm. In a broader perspective, Edvinsson, Gardarsdottir and Thorvaldsen (2008) state that the dissemination of information on infant care and the ability to read and to write also led to the leading position taken up by Denmark, Norway and Sweden in this field. This concurs with assessments made by contemporaries (Finkelnburg 1882; Prinzing 1899), whilst a link with 
real wages, which can also be used as an indicator of food status, is not presumed to exist for infant mortality at least in Scandinavia (Bengtsson/Lundh 1994). This means that main authors of both recent and older research are against the presumption which had been prevalent in historical demography for a long time since McKeown (1976), namely that the importance of public intervention was somewhat minor, whilst great significance should still be afforded in the 19th century to factors such as food status - in the case of the infants that of the mother (Floud 1991). For instance Spree (1986), in agreement with Lee (1984) - who however also includes women's workloads - also explains the West-East divide which is observable in Germany in the 19th century in this vein. In addition, he also admits that hygienic conditions exert a certain influence, but not healthcare. This approach disregards the fact that the latter might have been inseparable from the hygienic conditions. A different evaluation is therefore reached if one takes a closer look at the regional differences in the Eastern provinces of Prussia. The two factors, which are symptomatically expressed in the unequal successes achieved in the fight against child mortality, are therefore equally important when it comes to a certain West-East divide (Gehrmann 2010).

Women's workload proves to be of great importance among the social elements which have been regarded as determining factors for infant mortality since the end of the 19th century. This problem was already present at an early stage in the debate, so that it is also immediately mentioned in brief comments by the Prussian statistics. This is associated with factory work (Blenck 1886: LX). ${ }^{1}$ Older and more recent demographic research, which moreover concentrates on agriculture, in this context particularly includes the surveys by Prinzing (1899), Grass/ (1910), as well as Heller and Imhof (1983). Demographers have pointed to the regional differences in the division of tasks in agricultural societies (Wiegelmann 1975). As with the question on attitudes, local case studies have provided better access here in recent decades (e.g. Medick 1996). The family reconstitution method makes it possible also to include the family context. A certain obstacle however repeatedly emerges from the difficulty that the qualitative sources which are available for interpretation are not on the same level as the family data.

The advantage of the large databases which historical demography has generated on the same basis (Ortssippenbücher: village genealogies) for Germany is that they facilitate studies which can focus on both the family environment and broader contexts. Because of its size, the so-called Berlin database (Imhof 1990) is suitable for mortality surveys; it formed the basis of the study in which Kloke (1997) worked out the causes of infant mortality until the mid-19th century. In a large-scale comparison, the differences in breastfeeding (Knode/ 1968, 1988), that were recognised at an early stage, remain the key to an understanding of the noticeable contrast

1 “The difference in the ... mortality of children in their first year of life is partly explained by the fact that far fewer among the female population in Mecklenburg-Schwerin work in factories and other commercial facilities than in the Prussian State. [...] With some occupations in which female workers are preferentially employed, $[. .$.$] the deathbug is already implanted in the children$ in their mothers' womb." 
between Northern and Southern Germany. In her further analysis, she however opposes monocausal declarations, emphasising the differing interaction of individual factors at the microregional level.

Illegitimacy played a limited role in developments overall. Spree (1998) quantifies its explanatory value for Germany in greater detail. According to this research, only one-tenth of the increase in overall infant mortality can be attributed to the mortality of children born out of wedlock, this taking place in a period when out-of-wedlock births accounted for a relatively large share among all births. Hence, the inclusion of this factor, which is certainly interesting in other respects, can be neglected here. It also evidently does not explain the difference vis-à-vis the Jewish population (Derosas 2000), albeit this should be reviewed for Germany. In the most recent survey from the school of Knodel, Kintner (1994) revisits the topic of illegitimacy in her assessments of published statistics, and she also assesses it as being subordinate for explaining infant mortality. However, illegitimacy, together with urbanisation, acted to slow the fall in infant mortality. But, according to Kintner, the greatest influence was exerted by marital fertility; this link was particularly strong around 1900. In addition to more hygienic infant care, accordingly, the smaller number of siblings exerted a positive influence on the chances of survival.

For large-scale patterns, as well as for the difference between towns and country areas, the hypothesis stating that climatic circumstances had an effect on infant mortality should not remain neglected. In the absence of a better explanation, this idea was suggested at the start of the statistical evaluations (Würzburg 1887-1888), but it is also supported by more recent time series analysis (Ekamper et al. 2010). There is no doubt that seasonal temperature fluctuations, passed on and particularly amplified in the towns by the microclimate in dwellings (Prinzing 1899; Stöcke/ 1986) especially affected the mortality of infants who were not breastfed. There is however greater dispute whether this applies not only with regard to the regional differences at a specific time, but also to longer-term developments in the infant mortality rate (according to Perrenoud 1991, 1994). With his affirmation, Perrenoud (1994) refers to the statistical series on East Frisia and the Saarland from the Berlin database, in which a reduction has been recorded since the 1790s. He traces this back to the fall in the seasonal temperature differences. However, he does not say anything about the opposite problem of the continuous increase in infant mortality in the southern German areas which cannot be brought into line with it. The fact that the general increase or resurgence from the 1840s onwards took place with no recognisable link to the economic development of a region would also favour the influence of meteorological factors. Hypotheses of this kind can be examined using simple statistical series, given that climatic changes exert an influence in the same direction in major geographic connections. If they had been significant, they could therefore be expected to lead to similar changes in mortality in various regions.

If the presentation of robust statistical series on infant mortality is stressed as a central concern here, this is because only a small quantity of information is available for Germany so far, and some of it is misleading. In the international context, in fact, only Mitchell (2007) provides data on Germany in his set of figures for 1750-2005. These have for instance also been included in the GESIS dataset entitled "Geschich- 
te der deutschen Bevölkerung seit $1815^{\prime \prime} .^{2}$ However, when attempting to make a graphical portrayal, it becomes clear that the statistics on which they are based cannot be used as they are. There are leaps at various points in time which can only be explained by the successive broadening of the databasis. Mitchell starts with Bavarian figures (from 1836), afterwards Saxony is included (from 1851 onwards), Prussia is not taken on board until 1875. This finding makes clear both the need to take better advantage of and to document the quantitative sources, and the problem of the representativeness of the regional figures from which national series are to be created. Firstly, the older Prussian figures may not be overlooked, and secondly Bavaria was presumably anything but representative. Moreover, the Prussian statistics prior to 1875 have already been used (Spree 1998; Gehrmann 2000) and are also known in the English literature (Knode/ 1974). A reconstruction already also exists for Baden-Wuerttemberg. However, the sources have not been marked clearly enough as being partial, i.e. in some cases only covering Baden (Steinki) Prist//Gröner 1989).

\section{$3 \quad$ Data and data processing}

The collection entitled "Bevölkerung und Wirtschaft 1872-1972" (Statistisches Bundesamt 1972), which is still authoritative for long series on German population history, can only provide figures on infant mortality from 1901 onwards, in line with the information contained in the Statistical Year Books of the German Reich. Surveys on infant mortality had previously been exclusively a matter for the Federal States. The Reich statistics, established in 1871, did not require them to provide any information on the age of the deceased, but only to make a distinction between live and still births, the latter being defined as "children born after at least six months" pregnancy who died before or during birth" (translated by CPoS; Kaiserliches Statistisches Amt 1913: 25 - from where the following information was also obtained). The need for a more detailed distinction was formulated as far back as in 1868, but its implementation was largely left up to the individual Statistical Offices. In its annual mortality statistics, the Imperial Statistical Office limited itself to reproducing the information provided to it on the month of death and sex. It was not until the resolution of the Bundesrat of 6 December 1900 that an end was put to this unsatisfactory state of affairs with effect from 1901, and a uniform age classification was prescribed for the German Reich. Infant mortality was additionally distinguished from 1910 onwards according to the legitimacy of the children and by age in months.

The Imperial Reich's federal structure therefore caused gaps in the printed statistics on infant mortality prior to 1901 . More than that, it is obvious that no such information was enquired from registry offices of some states, or at least not from the beginning. When the Imperial Statistical Office wished to draw up the first life table for the German Reich in the 1880s, it therefore ascertained that "almost all

2 http://www.histat.gesis.org 
types and degrees of specialisation customary in statistics were found" in the individual states (Kaiserliches Statistisches Amt 1887: 21; translated by CPoS) but that still no suitable documents could be obtained from some of them. Nonetheless, the life table finally covered $96.8 \%$ of the population of the Reich in 1885 and $97.3 \%$ of live births in $1872-80 .^{3}$ This allows identifying the annual infant mortality rate from 1872 onwards, given that it can be derived from the materials on the calculation of the life tables. It was not yet possible to include the states Saxony-Coburg-Gotha, Mecklenburg-Strelitz, Waldeck, Lippe and Schaumburg-Lippe in the tables for the decades 1881 to 1890 and 1891 to 1900 . A representativeness level of $98.99 \%$ in relation to the number of inhabitants in 1900 was however already achieved for 1891/1900 (Kaiserliches Statistisches Amt 1913: 29; Kaiserliches Statistisches Amt $\left.1910,2^{*}\right)$. This value must be regarded as the upper limit for the 19th century. In addition to the restrictions that have been mentioned, Knodel (1974) had no access to the data from Thuringia, the principality of Luebeck, Birkenfeld and Anhalt for his work, so that his data collection is less complete, although it still remains highly useful as a secondary source in the context of the European Fertility Project.

With the aid of the life table material, it is therefore possible to extend the statistical series from "Bevölkerung und Wirtschaft" almost thirty years back. Values are available from 1872 onwards which are so highly representative (> $95 \%$ ) that they would not undergo any significant changes if one were to add the few missing data items.

The situation is more complicated for periods further in the past. It is basically irrelevant that the statistics of the population movement prior to 1875 were calculated by the religious communities in almost all German states. In doing so, they were carrying out state tasks and were hence subject to state agencies which sanctioned irregularities and ensured that the provided material was complete. With the establishment of Statistical Offices in the individual states, the collection of demographic information was allocated to a separate branch of the administration, but the foundations remained the same as in what is perhaps best referred to as the protostatistical era. This went back as far as the 17th century in some states. The surveys of early demographic statistics sometimes produce information on infant mortality, such as Prussia under Frederick the Great, whilst in other states, such as the stragglers named above, statistics remained rudimentary to the end or were based on an unsuitable distribution of the age groups. Differentiated information on demographic movements was also already published prior to 1871 , and this sometimes still took place retrospectively on the basis of the repositioned documents after the establishment of the Reich. In some smaller states, however, neither one nor the other was carried out although the records would have been available. Sometimes

3 This rate can be improved further by including Hamburg and Bremen. These states were not included in the life tables for $1871 / 72$ to $1880 / 81$ because the high age groups were not adequately attributed. Würzburg (1887-1888) was able to ascertain further data on infant mortality $1875-1877$, so that only Saxony-Coburg-Gotha is totally excluded from his publication for the Imperial Health Office. At that time, still further material was therefore available in the Central Statistical Authorities of smaller states. 
they remain in the archive stocks to this day. However, the corresponding analysis with small states such as Reuß Elder Line ( $0.1 \%$ of the births of the Reich) is not profitable since the data to be collected do not affect the overall values for the area of the subsequent German Reich. They can remain the subject of later investigations.

As is customary in historical-demographic statistics, the reference territory for the 1816-1871 period is defined as the German Reich within the borders of 1914, but not including Alsace-Lorraine. In statistical terms, this involves 32 territorial units, since Hanover, the Hesse Electorate, Frankfurt, Homburg, Nassau and SchleswigHolstein-Lauenburg are historically to be separated from Prussia, and the parts of Coburg and Gotha of the state Saxony-Coburg-Gotha had differing statistical systems. ${ }^{4}$ It is hence a matter of calculating infant mortality values for this whole which can be used as the German values in an international comparison. Such values will not be contested when they are based on a coverage which is similar to that of the Reichsstatistik from 1872, but they have to be justified, when the representativeness is lower. It must be noted that a simple extrapolation of known values cannot be done a priori, since there is no guarantee that the values of the undocumented areas were similar to the values of the documented parts of Germany. However, the inclusion of the Prussian statistics already makes the situation much more favourable than as portrayed by Mitchell (2007). Mortality for Prussia is documented from 1816 onwards, and the state does represent half of the reference territory $(50.7 \%$ of births 1841/50). After the annexations which took place in 1866, the values of Prussian infant mortality were very close to the Reich values. ${ }^{5}$ It will be necessary to investigate whether this was also the case for the preceding period.

Because of the major regional differences, however, the Prussian values or a dataset dominated by them should not be simply extrapolated. It is instead recommended to start by taking small steps and replacing the missing values in individual territories with probable ones. These emerge primarily when comparing the infant mortality values of neighbouring areas at different times. Thus, for Wuerttemberg prior to 1859 the information combined to form longer periods can be reduced to individual years by presuming the same spreads over the years as in Bavaria. For the Grand Duchy of Hesse, for instance, the clear analogies to the Hesse Electorate can be used for supplementation. Secondly, the child mortality rates can also be evaluated assuming that, if the likelihood of survival is identical at ages 2, 5, 10, 14 or 15 , the likelihood of survival until the first birthday must also have been highly similar since, by virtue of its considerable magnitude, the latter was a determining

4 The Schleswig-Holstein values do not always contain Lauenburg, which constitutes a special problem, although it is negligible because of its smallness. The independence of the two Hohenzollern and of two Anhalt states, as well as of a principality of Reuß until a certain time prior to 1866, is also insignificant here, as are territorial changes in Thuringia prior to 1830; this is because there is in any case no early information on infant mortality for any of these areas.

5 Prussian infant mortality as a mean of the annual values in 1872 to 1901 was $98.5 \%$ of the rate for the Reich as a whole, ranging from $94.2 \%$ to $102.5 \%$. 
factor for all other age groups just named and mortality was subject to less marked structural variations after the first year of life. How this was done in detail can be derived from the methodical remarks in Appendix 1. All the values calculated refer to live births. ${ }^{6}$ This principle was retained here although it does not reflect the contemporary understanding which is also expressed in the sources. A brief excursion on the definitions in the sources and on the problem of registration of the stillbirths is hence necessary here.

The statistics of the 19th century generally stated both births and deaths, including stillbirths. The latter were stated separately, but were not always registered

Fig. 1: Annual data on infant mortality, 1816-1871

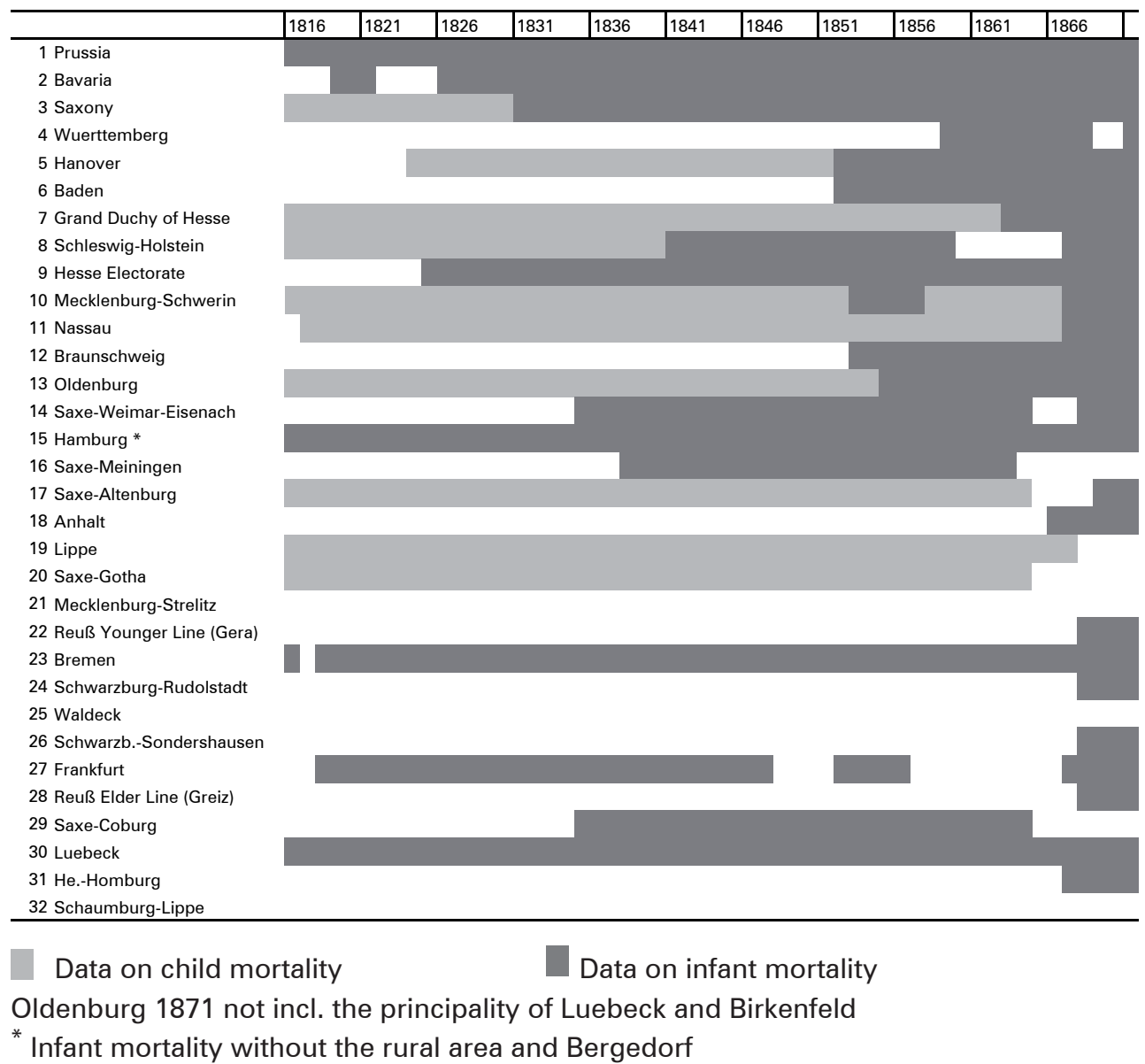

Source: see statistical references.

$\overline{6}$ They do not refer to the civil year in all states. This inaccuracy has to be accepted. 
Fig. 2: Representativeness of the individual states and territories, 1841/50

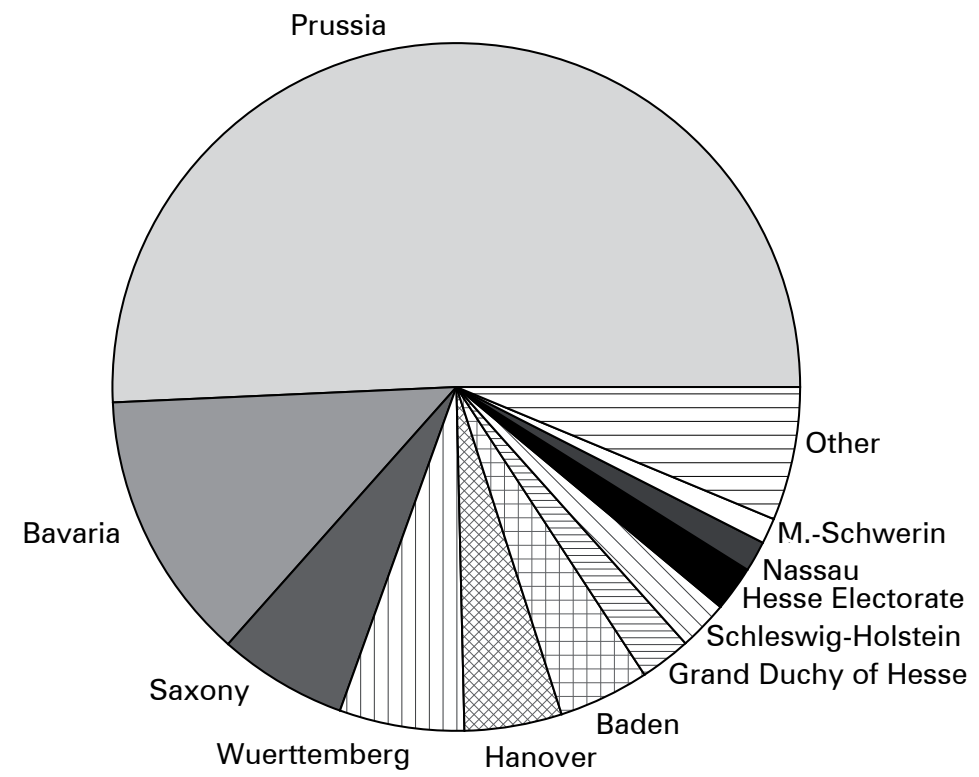

Source: Statistik des Deutschen Reichs, N.F. 44, 1892.

correctly. This especially applies to Catholic areas. The apparent stillbirth rate was too low there and the apparent infant mortality rate somewhat too high, because many stillbirths were declared as live births. Only for Mecklenburg-Schwerin does the opposite constellation occur in which many cases could be wrongly evaluated as stillbirths, since the statistics do not contain a special column for children who were born alive, but died before baptism. Because of the methods used by different denominations to distinguish between stillbirths, on the one hand, and live births which died on the day of birth, on the other, a separation factor was also used in historical analysis carried out on the basis of precise information of the birth and death data based on the original material from church records. The presumption underlying this factor is that, at that time, a similar share (roughly $3 / 4$ ) of the total number of children registered in all places as having died on the day of their birth actually were stillbirths (/mhof 1990). An analogous method would also be possible for Mecklenburg. In the interests of an accurate data documentation, the original information on live and stillbirths was not corrected, however.

The graphs (Fig. 1 and Fig. 2) show the representativeness of the figures available on infant mortality (Fig. 1, year box marked dark). The eleven largest areas together accounted for $93.7 \%$ of the births of the total reference territory of Germany in 1841/50 (Fig. 2). Gaps in the data of these states hence have a negative impact on the representativeness of the overall values, whilst the remaining 21 territorial units are virtually negligible in statistical terms. Taken individually, they never reached $1 \%$ of the total number of births. 
Tab. 1: Representativeness of the figures on infant mortality

\begin{tabular}{lcc}
\hline $\mathrm{a}$ & $\begin{array}{l}\text { Live births in the dataset per year } \\
\text { b } \\
\text { Share of } \mathrm{a} \text { in the number of births in Germany }\end{array}$ \\
& $\mathrm{a}$ & $\mathrm{b}$ \\
\hline $1819-21$ & 634,538 & .648 \\
$1826-30$ & 648,163 & .654 \\
$1831-40$ & 769,176 & .715 \\
$1841-45$ & 890,203 & .753 \\
$1846-51$ & 986,559 & .818 \\
$1852-66$ & $1,195,255$ & .920 \\
$1867-71$ & $1,378,671$ & .956 \\
\hline
\end{tabular}

Source: see statistical references.

The share of births on which information is available on infant mortality is vital in order to carry out an overall evaluation of the statistical material (Table 1). The reference value used here is based on the figures of the historical statistics of the German Reich (Vol. 44) from 1841 onwards, not including Alsace-Lorraine as has already been mentioned,. So far there is no such basis in published form for the period 1816 to 1841 , so that own calculations were carried out to determine the total number of births in which estimates have also been included. The procedure employed in the Reich statistics has been applied where possible.

\section{$4 \quad$ Results}

The complex procedure of supplementing missing data does not lead to significantly different results for the 1826-1871 period than the simple addition of the figures from the sources. The difference between the two series is no more than 0.9 percentage points per year, which in relation to the level of infant mortality at that time can be called only a slight deviation (Tab. 2, columns a and b in comparison). It is unlikely that the complete hundred percent values which cannot be ascertained here are significantly different since even unexpected, extreme and individual outliers in individual states with missing data cannot be realistically presumed to be so large that they could exert a sufficient influence on the overall values. This even applies to Wuerttemberg, which is relatively large, and for which the lack of raw data for the years 1869 and 1870 are somewhat disturbing. This creates a tenable basis for estimating the overall development (Table 2).

The first thing to notice is that the picture does not entirely correspond to the expectation expressed at the outset since developments in Prussia cannot be equated to those of the territory as a whole, namely the later German Reich. It is evident that the situation in the Southern German states was too different to that in Prussia before a kind of convergence set in following the establishment of the Reich which 
Tab. 2: Infant mortality in Germany, 1826-1914

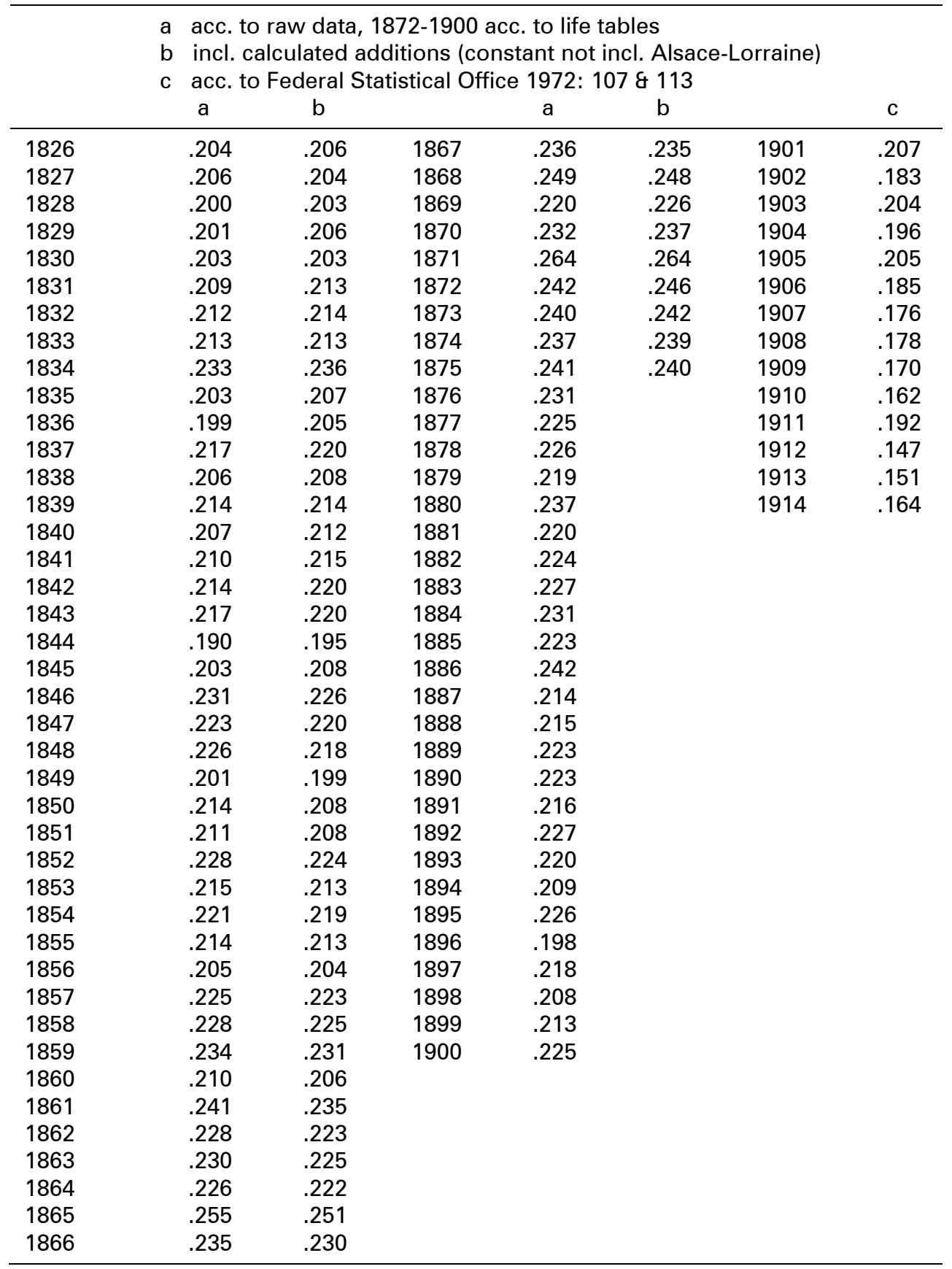

Source: see statistical references. 
led to a correspondence of the Prussian and Reich data. Such regional particularities play a vital role for Germany; they will be analysed in greater detail later. All in all, after the positive estimates of the 1820s had been superimposed by opposite tendencies, stagnation at a high level was predominant, whilst the situation was particularly critical in the first half of the 1860s until the second half of the 1870s, with a value of $24.5 \%$ in the five-year period $1871 / 75$. The epidemiological environment was extremely unfavourable during this period, this having corresponding effects on infants. The 1871/72 smallpox epidemic in Prussia was symptomatic of this. Other causes of death such as diphtheria and typhus however also occurred extensively in this period (e.g. 1865), but cannot be quantified because of the inadequate death statistics, whilst the cholera epidemic of 1866 astonishingly did not leave a direct trace. Similar side effects of diseases which actually tend to target older children also occurred in England in this period, where scarlet fever was a specific problem (Woods 1994).

No real change took place even after 1872 in spite of the ebbing of the wave of uncontrolled epidemics which also left their traces in Scandinavia in the decades 1850-1870 (Bengtsson/Lundh 1994). The rising birth rate in the Gründerzeit (the "Founder Epoch") after the Franco-German war may have contributed to this. Whilst infant mortality subsequently fell slightly, the decisive mark of an irreversible sinking of around $10 \%$ was however not overstepped until 1901, which was already recognised by Knode/ (1974: 162). With its sustainably high values, Germany almost brought up the rear (Fig. 3) among those European states for which longer time series are available, exceeded only by Austria and Russia (Vallin 1989: 38). The divide in comparison to the Western states had tended to widen further towards the end of the 19th century. Was the course of infant mortality in Germany based on a similar pattern which was perhaps delayed, or did it follow a different path?

The comparison shows that there was indeed a model development (Sweden), but otherwise no uniform marching route. Nonetheless, various patterns are revealed, albeit only a representative selection of states is portrayed in Fig. 3 for reasons of clarity:

a. A continuous drop in infant mortality, starting shortly before the middle of the century: Sweden. Iceland follows, but on the basis of a very much higher level and with stronger outliers. The values in Norway, already starting very low, only fall slightly, and there are discontinuities in Denmark.

b. Stagnating infant mortality on a moderate level: England. Belgium shows similar characteristics, France ultimately following suit after seeming initially to develop according to the Swedish pattern.

c. Marked fall in infant mortality in the last third of the 19th century, starting from relatively high values, preceded by an increase: Netherlands. Italy followed a similar pattern - as far as documented by national statistics.

Like Austria, Germany cannot be positioned within this pattern. The fact that the mortality of infants did not reduce was not unusual per se (pattern b). This problem can be linked to industrialisation (Vallin 1989), and is even occasionally generalised for the 19th century (van de Walle 2005). What was unusual was rather the persist- 
Fig. 3: Infant mortality in Germany in an international comparison, 1825-1900 (5-years-moving averages)

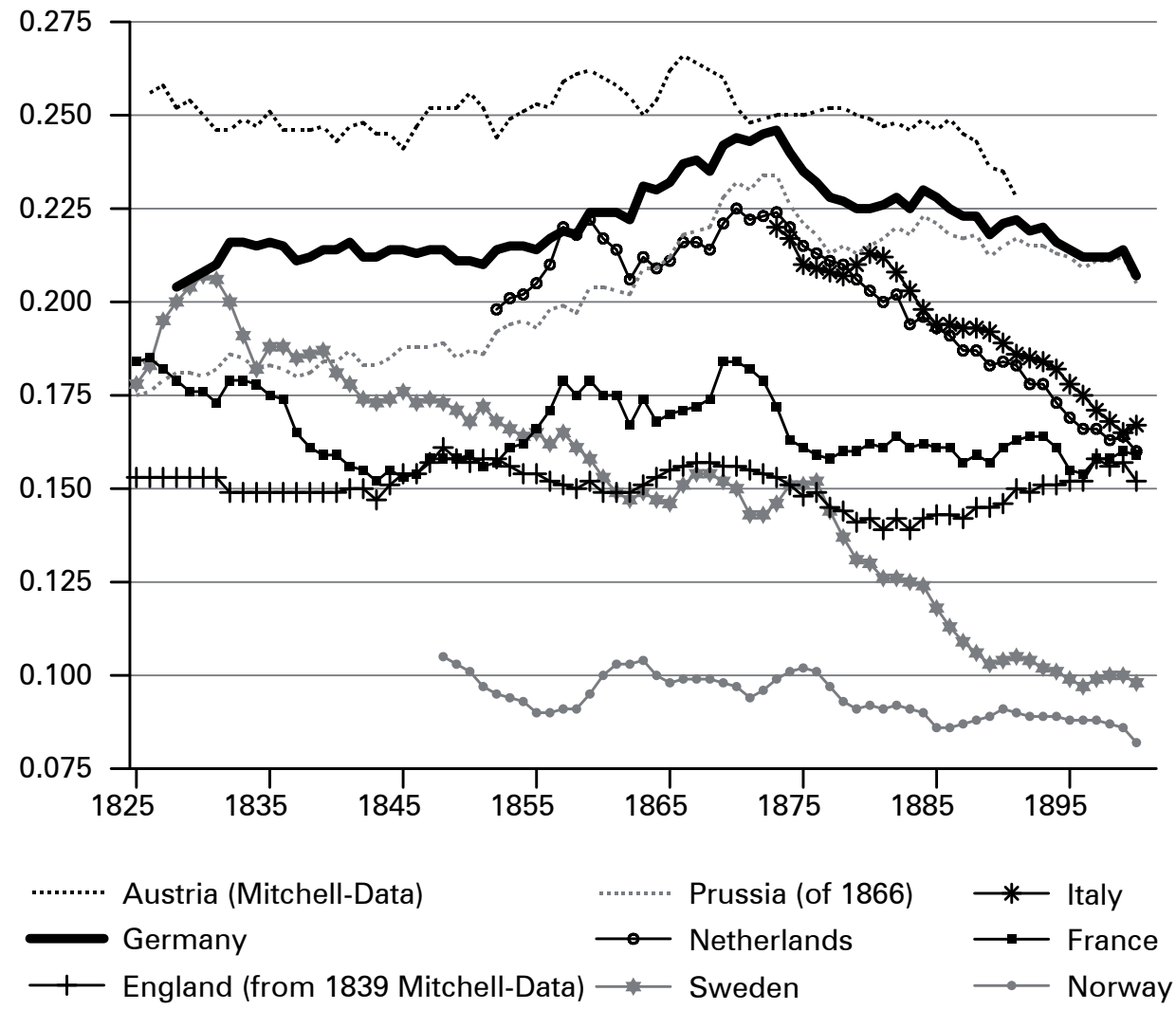

Source: Human Mortality Database, own calculations.

ence of this problem and the widening gap in comparison with the Netherlands (pattern c) for example. Germany was in any case far removed from the Scandinavian situation.

This should however not rule out conditions pertaining in parts of Germany that were similarly favourable to its Northern neighbours. This is already indicated by the so-called Berlin life tables (Imhof 1990). This poses the question as to the significance of the regional differences. Were they largely constant, or were there diverging developments? In the latter case, the analysis would also have a heuristic value for the interpretation of the overall course and of the factors influencing them.

The contrasts between the German states which are clearly recognisable in Fig. 4 had been formed at the latest in the second half of the 18th century (Imhof 1990), and the general difference between a high Southern German and a low Northern German infant mortality did not disappear at any time in the 19th century. Until the 1860s, the situation in Schleswig-Holstein, Hanover, Oldenburg (not shown) or Mecklenburg (combined in Fig. 4 with Schleswig-Holstein) was even better than 
Fig. 4: Infant mortality in the larger German states, 1825-1900 (5-years-moving averages)

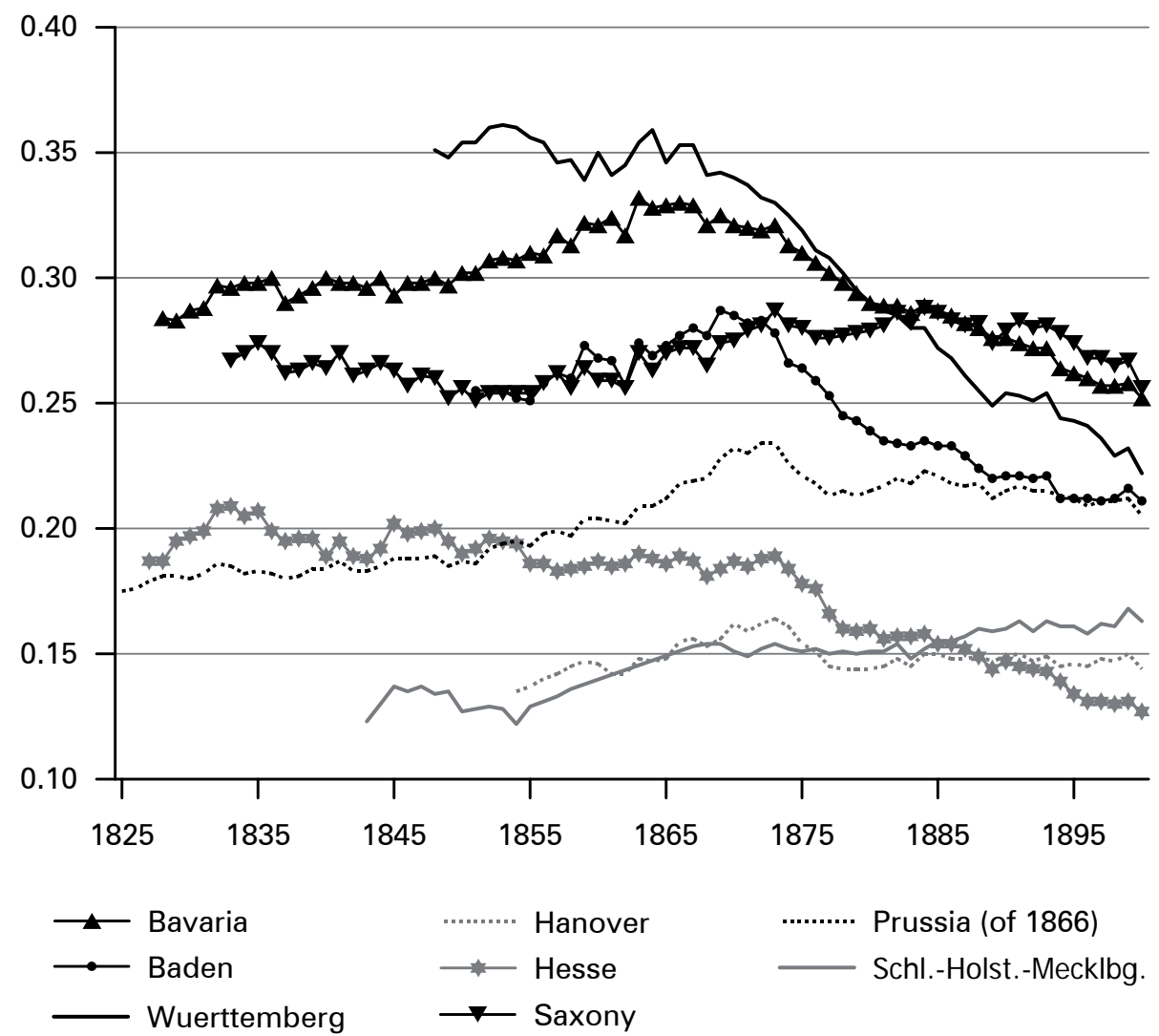

Source: see statistical references.

that in Sweden, which is shown as a model above. The common features shown in some of the Northern and Baltic areas hence suggest that one should not exclude natural and climatic factors from the outset, but that one should include population density. On the other hand, there were the Southern German states which were highly heterogeneous per se, but whose figures were negatively influenced by the widespread practice of not breastfeeding. However, progress was made there in the last third of the 19th century, whilst the situation did not improve in the industrial areas of Central Germany. In this period changes not only occurred in the problematic Southern German states, but also in other regions that were better off. If these were hence possible, the fact that they did not occur elsewhere may also indicate why Germany as a whole lagged behind comparable European states when it came to the survival chances of infants.

The following regional patterns can be identified which confirm Knodel's observations (1974) on the link between the amount of and progress in infant mortality: 
a. Western and Southern Germany: clearly-recognisable fall in the infant mortality rate, partly from a high and previously even rising level (Bavaria, Wuerttemberg, Baden), and partly from a moderate level (Hesse). There are similarities to the development in infant mortality in the Netherlands and in Italy as far as figures are available. This progress meant that conditions for the survival of infants were ultimately better in Hesse than in Schleswig-Holstein or Mecklenburg.

b. Central Germany: slight or no improvements. This is shown clearly in Saxony and is to be analysed more closely for Prussia. Schleswig-Holstein and Mecklenburg show a similar pattern, albeit the total infant mortality rate was much lower there. The values in Hanover remained largely unchanged.

Because of its size, Prussia must be looked at more closely. What is interesting here is both the East-West divide and the problem of the attribution of individual regions to the two patterns named. The mentioned difference can be determined from the outset to a certain degree, but no uniform picture emerges overall. For instance, Silesia and the Leipzig Basin area bordering on Saxony to the North already showed high infant mortality in the $1820-34$ period, whilst Pomerania, which is further East, apart from the Oder estuary, was equated to the Baltic Sea area further West (Gehrmann 2010). The second criterion for an attribution, the course of progress, can be obtained from comparing the periods of 1833/37 (own data collection) and 1875/80 (printed statistics, compiled by Knode/ 1974) (Table 3).

The values also fell in areas of Prussia in which they had previously been particularly high, and vice versa. This tendency to converge was however initially limited to reducing the extremes, whilst regional differences were not levelled out. On the contrary, they were accentuated when taken as a whole. Apart from the administrative districts of Koeslin and Erfurt, all the Central and Eastern German areas therefore reached higher scales, whilst all the Western German areas apart from Cologne show values below $20 \%$. The increase in Prussian infant mortality was largely due to the unfavourable development shown in the catchment area of the city of Berlin and in Eastern and Western Prussia. The initially negative effects of urbanisation caused by industrialisation (Vögele 1997), which are also recognisable in the data presented here for Hamburg, were therefore certainly present, but quite obviously do not reflect the only social problems which had fatal consequences. It is also likely that an explanation based on the fostering system, which has not been investigated so far, and which affected the surrounding areas starting in the towns, is ineffective. Rather, additional factors appear to have come into play which, when taken together, worsened rather than improved the living conditions of infants.

Such an absence of progress does not have to contradict an increase in the general standard of living, given that the connection between the parents' material security and the survival chances of their children was anything but linear. For instance, it is frequently observed in historical demography that infant mortality was lower among unpropertied agricultural labourers than it was among farmers (Schlumbohm 1992; Bengtsson/Lundh 1994; Sponholz 1995; Kloke 1997; Stephan 2002), so that the poorer families were better off in this respect than the richer ones. It is however certain on the other hand that the progress made at the turn of the 20th century started in the towns. There, in turn, it firstly became noticeable among civil 
Tab. 3: Changes in infant mortality rates in central administrative districts

\begin{tabular}{|c|c|c|c|c|}
\hline No. & (Knodel 1974: 288) & $1833 / 37$ & $1875 / 80$ & $\pm \%$ \\
\hline 1 & Ostpreußen & .182 & .218 & 19.6 \\
\hline 2 & Danzig & .192 & .235 & 22.7 \\
\hline 3 & Marienwerder & .181 & .226 & 25.1 \\
\hline 4 & Berlin & .228 & .304 & 33.2 \\
\hline 5 & Potsdam & .174 & .254 & 46.2 \\
\hline 6 & Frankfurt / Oder & .166 & .220 & 32.8 \\
\hline 7 & Stettin-Stralsund & .156 & .215 & 37.5 \\
\hline 8 & Köslin & .147 & .166 & 13.2 \\
\hline 9 & Posen & .191 & .216 & 13.3 \\
\hline 10 & Bromberg & 177 & .215 & 21.7 \\
\hline 11 & Breslau & .239 & .274 & 14.5 \\
\hline 12 & Liegnitz & .279 & .289 & 3.7 \\
\hline 13 & Oppeln & .209 & .212 & 1.6 \\
\hline 14 & Magdeburg & .172 & .219 & 27.0 \\
\hline 15 & Merseburg & .201 & .214 & 6.6 \\
\hline 16 & Erfurt & .162 & .186 & 15.0 \\
\hline 24 & Münster & .139 & .150 & 7.6 \\
\hline 25 & Minden & .156 & .151 & -3.1 \\
\hline 26 & Arnsberg & .128 & .151 & 18.1 \\
\hline 27 & Kassel & .207 & .164 & -20.9 \\
\hline 29 & Koblenz & .170 & .179 & 5.5 \\
\hline 30 & Düsseldorf & .140 & .166 & 18.9 \\
\hline 31 & Köln & 157 & .202 & 28.9 \\
\hline 32 & Trier & .143 & .157 & 9.4 \\
\hline 33 & Aachen & .165 & .193 & 16.7 \\
\hline 35 & Oberbayern & .380 & .383 & 0.8 \\
\hline 36 & Niederbayern & .337 & .348 & 3.1 \\
\hline 37 & Pfalz & .177 & .179 & 0.9 \\
\hline 38 & Oberpfalz & .314 & .327 & 4.2 \\
\hline 39 & Oberfranken & .214 & .192 & -10.1 \\
\hline 40 & Mittelfranken & .293 & .286 & -2.4 \\
\hline 41 & Unterfranken & .241 & .207 & -14.0 \\
\hline 42 & Schwaben & .400 & .383 & -4.1 \\
\hline 43 & Dresden & .257 & .267 & 3.9 \\
\hline 44 & Leipzig & .262 & .266 & 1.5 \\
\hline 45 & Zwickau & .278 & .303 & 8.9 \\
\hline 66 & Lübeck & .184 & .178 & -3.0 \\
\hline 67 & Bremen & .151 & .171 & 12.9 \\
\hline 68 & Hamburg & .164 & .219 & 33.3 \\
\hline
\end{tabular}

Source: see statistical references. 
servants and self-employed persons (Vögele 1997; Spree 1980; cf. Woods 1994; Sundin 1995). All in all, infant mortality did not sustainably fall until the "urban handicap" disappeared, hence paving the way towards the value of $10 \%$, which at that time could be regarded as optimal.

In addition to urbanisation, and connected to this migration and population density, still another demographic condition is to be observed, namely fertility. The causality which was identified early and appears plausible according to which a fall in infant mortality had to be preceded by a drop in fertility (van de Walle 1986; Preston 1978) cannot be upheld for Germany. Rather, there was a connection with the drop in fertility which is insoluble, or which rather has yet only been insufficiently solved by analysis.

Prior to the transformation in fertility behaviour, there was not yet a positive correlation between the two events at least in Prussia. The gross reproduction rate which can be estimated relatively reliably because of the age distribution of deaths and the natural growth rates, did not increase there parallel to infant mortality, but fell until after the middle of the century. This also applied to Potsdam administrative district, where the greatest increase in infant mortality was registered. Particularly informative is the inclusion of natality when observing developments in Hesse, since this region serves here as an example of an early fall in infant mortality from a level that was already moderate, and hence can be regarded as a German counterpart to Sweden. The birth rate in Hesse in the 1850s was relatively low, and this was probably also linked to emigration. Then it initially increased, but subsequently fell once more. Whilst no unambiguous correspondence with a movement in infant mortality can yet be registered for the first fertility reduction, if it was real at all and not simply a result of the age structure, ${ }^{7}$ such a reduction is clearly revealed in the second half of the 1870s. Thus, it can be concluded that a changed interaction between infant mortality and fertility behaviour only came about in a new historic context, and was perhaps unable to do so until such a change had taken place.

\section{Discussion}

Hopefully, the results presented here will provide an impetus for further studies of the topic of infant mortality in historic Germany. Regardless of the more exact analyses of certain connections that have to be carried out in the future, the presented overview of the main international and interregional differences already enables one to comment on individual hypotheses of the research.

The climatic hypothesis, which met with both approval but also disagreement at an early date (Krull 1874), proved to be relatively unhelpful for our analysis. There is no denying that it can help to explain short-term fluctuations, and perhaps also

7 The mortality statistics of the Hesse Electorate provide age distributions for deaths. The age groups are however relatively broad, so that model life tables have to be used in order to then estimate the gross reproduction rate. 
favourable periods such as the 1820s. However, it can no longer be regarded as a decisive factor for the main part of the period surveyed. This already emerges from a synopsis of the data series presented here, since they were not subject to manifestly parallel influences.

However, the approaches which are based on social factors can generally be agreed with. They necessarily focus on the workload of women, even if it cannot always be quantified or made amenable to measure in another form (Vallin 1989). The differences in this area, however, cannot be simply ascribed to an East-West divide, as happens with Lee (1984) referring to agricultural property ownership. This is contradicted by the example of Eastern Pomerania with its extremely good survival chances, and farmers in Mecklenburg were also not better off than elsewhere in the areas to the East of the Elbe. There therefore remains some analysis to be done and concretisation to be carried out. Especially the distribution of tasks in the countryside has to be analysed. Furthermore, the indications of Wiegelmann (1975), mentioned above, should be explored, since they suggest that the position of the Baltic area was more favourable in this respect from the Middle Ages onwards. The contemporary literature also offers some source material on this topic.

The first provisional answer to the question of why Germany had such a high infant mortality and why it was so difficult to limit it for a long time, must therefore be that the latter was by no means unusual in industrialised states with a high degree of urbanisation. Additionally, however, the conditions in the area of the German Reich, when taken as a whole, were much worse than elsewhere. Unfavourable regional developments already occurred prior to 1815 when it came to breastfeeding and infant care which were due at least as much to attitudes as to social conditions. The forces of population pressure and population regulation may have been just as effective in the background. These regional differences, which have become constants, were now supplemented by new ones. They express a worsening in living conditions of infants. Such a development was observed both in the towns and in the countryside, in particular in the central provinces of Prussia. The term "women's workloads" is the key to this development.

It is equally important here to point out that the findings support some known or somewhat neglected observations made by contemporaries and historical demographers. For instance, it may be regarded as certain that the reduction in fertility was accompanied by a drop in infant mortality (Knode/ 1974; Kintner 1994), albeit one event was not the chronological consequence of the other. One can therefore conclude that both events were determined by a change in attitudes. Where this was expressed in a corresponding health policy, it did not remain hidden (Prinzing 1899; Vögele 2010). The observations discussed so far however tend to refer to the 20th century rather than to the 19th, which is the one we are interested in here. However, there were already unmistakeable reductions in infant mortality which have been characterised above as the Western and Southern German pattern. They are reminiscent of the reduction which took place several decades before (Gehrmann 2002), also regionally-limited, in which a change in breastfeeding and infant care is manifest. The fact that this event has been virtually disregarded in the research carried out so far may have been caused by the fact that it still took place in the context of 
the old demographic circumstances, and not in the process of transition, which received greater attention. Lessons could certainly also be drawn from patterns which occurred earlier for the interpretation of subsequent changes - or their delay.

There has for quite some time no longer been a shortage of medical insight in the field of infant care (Rau 1840; Fischer 1965), and the very low infant mortality among the Jewish population of Prussia is only one example of certain population groups in which the optimal $10 \%$ mark was certainly already a realistic orientation (Wappäus 1859: 215). It is obvious that from a certain time onwards the attempts were intensified to engage in popular education, as can also be demonstrated for Sweden. For instance, Krull (1874: 144) quotes a paper which appeared at a time when the high child mortality in Wuerttemberg finally began to fall ("Die Kindersterblichkeit in Wuerttemberg: Eine Mahnung an das Volk, 1868"). These had been preceded by detailed research carried out by the Physikate (local public health offices) that had been ordered by the medical board in 1858. In this context, the education of women already appeared to them as the key to combating infant mortality, in its effects that were defined in early infant mortality (Finkelnburg 1882). The degree to which new knowledge could be implemented primarily depended on the attitudes, and then on the social circumstances. The discussion of the question of what this meant in concrete terms in 19th century Germany, and what conclusions can be drawn from this in terms of continuity and change in society, is still underway.

\section{Statistical references}

Preußen 1816-1860: Engel, Ernst 1861-1862. Die Sterblichkeit und die Lebenserwartung im preußischen Staate und besonders in Berlin. Zeitschrift des kgl. Preußischen Statistischen Bureaus 1-2; 1861-1874: Preußische Statistik 5, 10, 18, 29, 43, ab 1875 Datenbank Patrick Galloway. / Bayern 1819-1821: Gebhard, Dismas A. 1844. Über Wittwen- und Waisen-Pensions-Anstalten nebst Bemerkungen über Lebens-Versicherungs-Anstalten. München; 1826-1844: Beiträge zur Statistik Bayerns 1 (1850); 1845-1888: Beiträge zur Statistik Bayerns 3, 8, 11, 33, 37, 38, 43, 56; 1889-1898: Generalberichte über die Sanitätsverwaltung im Königreiche Bayern; 1899-1900: Statistik des Deutschen Reichs 200 (1910). / Sachsen 1831-1833:Statistisches Jahrbuch für das Königreich Sachsen 1907, 71; 1834-1864: Knapp, Georg F. 1869. Die Sterblichkeit in Sachsen nach amtlichen Quellen dargestellt. Leipzig: Duncker \& Humblot; 1865-1875: Geissler 1876. Vergleichende Statistik der Geburts- und Sterblichkeitsverhältnisse in Sachsen von 1834-1875. Zeitschrift des Kgl. Sächsischen Statistischen Bureaus 22, 361-367; 1874-1907: Statistisches Jahrbuch für das Königreich Sachsen 1909. / Württemberg 1812-1822: Gang der Bevölkerung des Königreichs in den 10 Jahren von 1812 bis 1822 . Württembergische Jahrbücher für vaterländische Geschichte, Geographie, Statistik und Topographie 1824, 115-126; 1846/47-1855/56: Sick, Paul 1856. Zahl und Verlauf der Geburten in dem Königreiche Württemberg während der 10 Jahre 1846-1856. Württembergische Jahrbücher für vaterländische Geschichte, Geographie, Statistik und Topographie, 1-99; 1846/47-1855/56: Die Sterbefälle unter der ortsanwesenden Bevölkerung Württembergs während des Decenniums 1846-56. Württembergische Jahrbücher für vaterländische Geschichte, Geographie, Statistik und Topographie 1862 (1), 144-204; 1858/59 - 1868: Cless 1860-1870. (Jahresberichte über die) Geburts- und Sterblichkeitsstatistik Württembergs, mit Einschluss der Statistik des Heilpersonals, vom Verwaltungsjahre .... Medicinisches Correspondenz-Blatt des Württembergischen Ärztlichen Vereins 30-37, 40; 1871-1899: Losch, 
Hermann 1900. Die Bewegung der Bevölkerung Württembergs im 19. Jahrhundert und im Jahre 1899. Württembergische Jahrbücher für Statistik und Landeskunde(2), 56-165; 1900: Statistik des Deutschen Reichs 200 (1910). / Hannover 1852-64: Zur Statistik des Königreichs Hannover 4, 5, 7, 9. 11; 1865-1866: Zeitschrift des Königl. Hannoverschen Statistischen Bureaus, 2, 3. / Baden 1852-1895: Behrens, Richard 1904. Der Verlauf der Säuglingssterblichkeit im Großherzogthum Baden von 1852 bis 1895, in Ministeriums des Innern (Hg.): Beiträge zur Statistik der inneren Verwaltung des Großherzogthums Baden: H. 46. Karlsruhe: Müller, 3-23, 1896-1900: Statistik des Deutschen Reichs 200 (1910), 126, 131. / Ghzt. Hessen 1863-1875: Beiträge zur Statistik des Großherzogthums Hessen, 10, 17, 30; 1876-1900: Statistisches Handbuch für das Großherzogtum Hessen 1903. Darmstadt: Jonghaus, 1:43. / Schleswig-Holstein 1840-1859: Statistisches Tabellenwerk 2 (1846), Statistisk Tabelvaerk N.R. 17 (1858), 3.R. 1.2 (1863); ab $1867 \mathrm{~s}$. Preußen. / Hessen-Kassel 1825-1866: Metz, Ludwig 1871. Statistische Beschreibung des Regierungs-Bezirks Cassel. Unter Benutzung amtlicher Quellen. Kassel: Kay; ab 1867 s. Preußen. / Mecklenburg-Schwerin 1853-1857, 1867-1884: Beiträge zur Statistik Mecklenburgs 1, 10; 1886-1907: Statistisches Handbuch für das Großherzogtum Mecklenburg-Schwerin 1910. / Nassau-Wiesbaden: ab 1867 s. Preußen. / Hamburg 1792-1819: Neefe, M. 1878. Ältere Nachrichten über Hamburgs Bevölkerungswechsel. Statistik des Hamburgischen Staates 8(2), 66-70; 1820-1900: Die Gesundheitsverhältnisse Hamburgs im neunzehnten Jahrhundert. Den ärztlichen Theilnehmern der 73. Versammlung Deutscher Naturforscher und Ärzte gewidmet von dem Medicinal-Collegium 1901. Hamburg: Voss. / Bremen 1812-1825: Reineke, Karl 1928. Geburten und Sterbefälle in der Stadt Bremen, 1700-1825. Mitteilungen des Statistischen Landesamtes Bremen, 2; 1826-1900: Böhmert, Wilhelm 1926. 100 Jahre Geburtenstatistik in Bremen nebst Angaben über die Säuglingssterblichkeit. Bremen: Hauschild (Mitteilungen des Statistischen Landesamts Bremen im Jahre 1926) .

\section{References}

Bengtsson, Tommy; Lundh, Christer 1994: La mortalité infantile et post-infantile dans les pays nordiques avant 1900. In: Annales de Démographie historique: 23-43.

Blenck, Emil (Eds.) 1886: Zeitschrift des Königlich Preußischen Statistischen Bureaus 26.

Corsini, Carlo A.; Viazzo, Pier P. (Eds.) 1997: The Decline of Infant and Child Mortality. The European Experience, 1750-1990. Den Haag: Martinus Nijhoff.

Derosas, Renzo 2000: When Culture Matters: Differential Infant and Child Mortality of Jews and Catholics in 19th-Century Venise. Oslo: Comité International de Démographie historique.

Edvinsson, Sören; Gardarsdottir, Olöf; Thorvaldsen, Gunnar 2008: Infant mortality in the Nordic countries, 1780-1830. In: Continuity and Change 23: 457-485.

Ekamper, Peter et al. 2010: Heat waves and cold spells and their effect on mortality: An analysis of micro-data for the Netherlands in the nineteenth and twentieth centuries. In: Annales de Démographie historique 2: 55-104.

Finkelnburg, Karl 1882: Über den hygienischen Gegensatz von Stadt und Land. In: Zentralblatt für allgemeine Gesundheitspflege 1: 4-15, 43-54.

Fischer, Alfons 1965: Geschichte des deutschen Gesundheitswesens. Hildesheim: Olms. 
Floud, Roderick 1991: Medicine and the Decline of Mortality: Indicators of Nutritional Status. In: Schofield, Roger; Reher, David; Bideau, Alain (Eds.): The Decline of Mortality in Europe. Oxford: Clarendon Press: 146-176.

Gehrmann, Rolf 2000: Bevölkerungsgeschichte Norddeutschlands zwischen Aufklärung und Vormärz. Berlin: Berlin-Verlag.

Gehrmann, Rolf 2002: Infant Mortality in Town and Countryside: Northern Germany, about 1750-1850. In: History of the Family 7: 545-556.

Gehrmann, Rolf 2010: Der demographische Umbruch vom 18. zum 19. Jahrhundert in Norddeutschland - ein auf die Gebiete östlich von Oder und Neiße übertragbares Modell? In: Uniwersytet Zielonogórski (Eds.): Przemiany demograficzne Europy Środkowej w czasach nowożytnych. Zielona Góra: Uniwersytet Zielonogórski: 231-253.

Grass/ 1910: Die sozialen Ursachen der Kindersterblichkeit in Bayern, insbesondere der Einfluß der agrarischen Verhältnisse auf die Kindersterblichkeit Bayerns und anderer Staaten. In: Zeitschrift für soziale Medizin 5: 374-402, 473-521.

Guttormsson, Loftur; Gardarsdottir, Olöf 2000: Public Intervention to Diminish Infant Mortality from Neonatal Tetanus in the Island of Vestmannaeyjar (Iceland) during the First Half of the Nineteenth Century. Oslo.

Heller, Geneviève; Imhof, Arthur E. 1983: Körperliche Überlastung der Frauen im 19. Jahrhundert. In: Imhof, Arthur E. (Eds.): Leib und Leben in der Geschichte der Neuzeit. Berlin West: Duncker \& Humblot.

Imhof, Arthur E. 1990: Lebenserwartungen in Deutschland vom 17. bis 19. Jahrhundert. Life Expectancies in Germany from the 18th to the 19th Century. Weinheim: VCH Acta Humaniora.

Kaiserliches Statistisches Amt (Eds.) 1873: Die Anordnungen des Bundesrathes für die gemeinsame Statistik der deutschen Staaten mit den vorbereitenden Verhandlungen, insbesondere den Protokollen und Berichten für die weitere Ausbildung der Statistik des Zollvereins. Berlin: Kgl. Preußisches Statistisches Bureau. (Statistik des Deutschen Reichs 1).

Kaiserliches Statistisches Amt (Eds.) 1887: Deutsche Sterbetafel, gegründet auf die Sterblichkeit der Reichsbevölkerung in den 10 Jahren 1871/72 bis 1880/81, nebst Vergleichungen mit anderen Sterbetafeln. In: Monatshefte zur Statistik des Deutschen Reichs 11: 1-65.

Kaiserliches Statistisches Amt (Eds.) 1910: Deutsche Sterbetafeln für das Jahrzehnt 1891 bis 1900. Berlin: Puttkammer \& Mühlbrecht. (Statistik des Deutschen Reichs 200).

Kaiserliches Statistisches Amt (Eds.) 1913: Das Arbeitsgebiet des Kaiserlichen Statistischen Amtes nach dem Stande des Jahres 1912. Berlin: Puttkammer \& Mühlbrecht. (Statistik des Deutschen Reichs 201).

Kintner, Hallie J. 1988: Determinants of Temporal and Real Variation in Infant Mortality in Germany, 1871-1933. In: Demography 25: 597-609.

Kintner, Hallie J. 1994: Infant Mortality Decline in Germany, 1871-1925: The role of changes in variables and changes in the structure of relations. In: Genus 50: 117-132.

Kloke, Ines 1997: „Kommts Abendroth, ists Kindlein todt“. Säuglingssterblichkeit in sechs ländlichen Regionen in Deutschland im 18. und 19. Jahrhundert. Berlin.

Knodel, John E. 1968: Infant Mortality and Fertility in three Bavarian Villages: An Analysis of Family Histories from the 19th Century. In: Population Studies 22: 297-318.

Knodel, John E. 1974: The Decline of Fertility in Germany, 1871-1939. Princeton: University Press. 
Knodel, John E. 1988: Demographic Behavior in the Past. A Study of Fourteen German Village Populations in the Eighteenth and Nineteenth Centuries. Cambridge etc.: University Press.

Krull 1874: Beiträge zur Statistik der Bevölkerung des Königreichs Württemberg. In: Württembergische Jahrbücher für Statistik und Landeskunde: 1-232.

Lee, W. Robert 1984: The Impact of Agrarian Change on Women's Work and Child Care in Early-Nineteenth-Century Prussia. In: Fout, John C. (Eds.): German women in the nineteenth century: A social history. New York: 234-255.

McKeown, Thomas 1976: The Modern Rise of Population. London: Arnold.

Medick, Hans 1996: Weben und Überleben in Laichingen 1650-1900. Lokalgeschichte als Allgemeine Geschichte. Göttingen: Vandenhoeck \& Ruprecht.

Mitchell, Brian R. 2007: International Historical Statistics: Europe 1750-2005. 6. Aufl. Houndmills, New York: Macmillan.

Perrenoud, Alfred 1991: The Attenuation of Mortality Crises and the Decline of Mortality. In: Schofield, Roger; Reher, David; Bideau, Alain (Eds.): The Decline of Mortality in Europe. Oxford: Clarendon Press: 18-37.

Perrenoud, Alfred 1994: La mortalité des enfants en Europe francophone: état de la question. In: Annales de Démographie historique: 79-96.

Preston, Samuel H. (Eds.) 1978: The Effects of Infant and Child Mortality on Fertility. New York.

Prinzing, Friedrich 1899: Die Entwicklung der Kindersterblichkeit in den europäischen Staaten. In: Jahrbücher für Nationalökonomie und Statistik 72: 577-635.

Rau, Wilhelm 1840: Worin ist die unnatürliche Sterblichkeit der Kinder in ihrem ersten Lebensjahre begründet, und wodurch kann dieselbe verhütet werden? Bern: Fischer.

Rott, Fritz 1929: Der Rückgang der Säuglingssterblichkeit. In: Grotjahn, Alfred; Langstein, Leo; Rott, Fritz (Eds.): Ergebnisse der Sozialen Hygiene und Gesundheitsfürsorge. Leipzig: Thieme: 85-134.

Schlumbohm, Jürgen 1992: Sozialstruktur und Fortpflanzung bei der ländlichen Bevölkerung Deutschlands im 18. und 19. Jahrhundert. Befunde und Erklärungsansätze zu schichtspezifischen Verhaltensweisen. In: Voland, Eckart (Eds.): Fortpflanzung: Natur und Kultur im Wechselspiel: Versuch eines Dialogs zwischen Biologen und Sozialwissenschaftlern. Frankfurt a.M.: Suhrkamp: 322-346.

Sponholz, Gerlinde 1995: Die Säuglingssterblichkeit in zwei ländlichen Gemeinden im 18. und 19. Jahrhundert. Konfessionell bedingte Werthaltungen als Risikofaktoren? Med. Diss. Universität UIm.

Spree, Reinhard 1980: Die Entwicklung der differentiellen Säuglingssterblichkeit in Deutschland seit der Mitte des 19. Jahrhunderts. Ein Versuch zur Mentalitäts-Geschichte. In: Imhof, Arthur E. (Eds.): Mensch und Gesundheit in der Geschichte. Husum: Matthiessen: 251-278.

Spree, Reinhard 1986: Veränderungen des Todesursachen-Panoramas und sozioökonomischer Wandel - Eine Fallstudie zum „Epidemiologischen Übergang”. In: Gäfgen, Gérard (Eds.): Ökonomie des Gesundheitswesens. Berlin: Duncker \& Humblot: 73-100.

Spree, Reinhard 1998: Der Rückzug des Todes. Der epidemiologische Übergang in Deutschland während des 19. und 20. Jahrhunderts. Historical Social Research 23: 4-43.

Statistisches Bundesamt (Eds.) 1972: Bevölkerung und Wirtschaft 1872-1972. Stuttgart, Mainz: Kohlhammer. 
Steinki, Paul; Pristl, Karl; Gröner, Gerhard 1989: Die Säuglingssterblichkeit in BadenWürttemberg. In: Jahrbücher für Statistik und Landeskunde von Baden-Württemberg: 5-64.

Stephan, Peter 2002: Ditfurt: Demografie und Sozialgeschichte einer Landgemeinde nördlich des Harzes über 400 Jahre. Wernigerode, Berlin: Lukas.

Stöckel, Sigrid 1986: Säuglingssterblichkeit in Berlin von 1870 bis zum Vorabend des Ersten Weltkriegs - Eine Kurve mit hohem Maximum und starkem Gefälle. In: Ribbe, Wolfgang (Eds.): Berlin-Forschungen, Bd. 1. Berlin: Colloquium: 219-264.

Sundin, Jan 1995: Culture, Class, and Infant Mortality during the Swedish Mortality Transition, 1750-1850. In: Social Science History 19: 117-145.

Vallin, Jacques 1989: La mortalité en Europe de 1720 à 1914. Tendances à long terme et changements de structure par sexe et par âge. In: Annales de Démographie historique: $31-53$.

van de Walle, Etienne 2005: Historical Demografy. In: Poston, Dudley L.; Micklin, Michael (Eds.): Handbook of population. New York, NY: Springer.

van de Walle, Francine 1986: Infant Mortality and the European Demographic Transition. In: Coale, Ansley J.; Watkins, Susan Cotts (Eds.): The Decline of Fertility in Europe. Princeton: University Press: 201-233.

Vögele, Jörg 1997: Urbanzisation, Infant Mortality and Public Health in Imperial Germany. In: Corsini, Carlo A.; Viazzo, Pier P. (Eds.): The Decline of Infant and Child Mortality. The European Experience, 1750-1990. Den Haag: Martinus Nijhoff: 109-127.

Vögele, Jörg 2010: "Has all that has been done lately for infants failed?" 1911, infant mortality and infant welfare in early twentienth-century Germany. In: Annales de Démographie historique 2: 131-146.

Wappäus, Johann Eduard 1859-1861: Allgemeine Bevölkerungsstatistik. Leipzig: Hinrich.

Wiegelmann, Günter 1975: Bäuerliche Arbeitsteilung in Mittel- und Nordeuropa - Konstanz oder Wandel? In: Ethnologia Scandinavica: 5-22.

Woods, Robert 1994: La mortalité infantile en Grande-Bretagne: un bilan des connaissances historiques. In: Annales de Démographie historique: 119-134.

Würzburg, Arthur 1887-1888: Die Säuglingssterblichkeit im Deutschen Reiche während der Jahre 1875 bis 1877. In: Arbeiten aus dem Kaiserlichen Gesundheitsamte 2-3: 20-222, 343-446, 28-108.

Translated from the original text by the Federal Institute for Population Research, for information only. The reviewed and author's authorised original article in German is available under the title "Säuglingssterblichkeit in Deutschland im 19. Jahrhundert", DOI 10.4232/10. CPoS-2011-22de or URN urn:nbn:de:bib-cpos-2011-22de3, at http://Www.comparativepopulationstudies.de.

Dr. Rolf Gehrmann ( $\bowtie)$. Europa Universität Viadrina Frankfurt (Oder), 15230 Frankfurt (Oder), Germany. E-Mail: guietgehrmann@aol.com URL: http://www.kuwi.europa-uni.de/de/lehrstuhl/kg/wisogeschi/Professurteam/ gehrmann/index.html 


\section{Appendix 1: Estimating and calculating missing infant mortality rates}

1. Retroactive extension: If both the infant mortality rate and child mortality rates are available for a later period, this ratio can be transferred to an earlier section of the 19th century for which the child mortality rate is known. This method is however only used here by way of exception since epidemic years had a stronger impact on the child mortality rate than on the infant mortality rate.

2. Conclusion by analogy that values are taken on from areas which are not too far apart and in which at other times the infant mortality rate, or the child mortality rate in general, were very similar.

3. The following detailed estimates were carried out for the missing infant mortality rates:

a. Saxony: 1826-1831 calculated from the child mortality rate,

b. Hesse: Homburg, Grand Duchy of Hesse, Nassau and Waldeck, values as Kurhessen,

c. Frankfurt: years 1847-50 in which there are gaps, as Hamburg,

d. Wuerttemberg: calculated from the Bavarian values (factor 1.172 - corresponds both to the $1818 / 21$ ratio (1.18) and to the $1847 / 56$ ratio (1.17))

e. Hanover and Braunschweig: infant mortality rate to 1851 and 1852, respectively, derived from ${ }_{2} \mathrm{q}_{0}$ for Lippe (factor 0.75 , as in the East Frisian life table 1820-1859),

f. Lippe and Schaumburg-Lippe: from 1852 as Hanover,

g. Mecklenburg-Schwerin: for 1826-52 as Ratzeburg (partial Land of Mecklenburg-Strelitz), for 1858-66 as Hanover,

h. Mecklenburg-Strelitz: as Mecklenburg-Schwerin,

i. Schleswig-Holstein: for 1826-40 as Ratzeburg, for 1860-66 as Hanover,

j. Oldenburg: until 1854 as Schleswig-Holstein (i.e. prior to 1841 as Ratzeburg)

k. Baden: for 1826-1851 as Saxony since the infant mortality rates are almost identical in 1852-63 (0.259/0.262),

I. Anhalt: as Prussia,

m. Altenburg: apart from 1826-30 (derived there from ${ }_{2} q_{0}$ ) as Saxony,

n. Reuß Elder line: as Altenburg,

o. Coburg: as Altenburg (until 1834 and 1865-67), then as Reuß Younger line (1868-71),

p. Reuß Elder line: as Coburg,

q. Gotha: from 1838 as Meiningen,

r. Meiningen, Weimar: before 1838 and 1835, respectively, the values derived from ${ }_{2} q_{0}$ values for Gotha; Meiningen 1868-71 as Weimar; 1865-67 as Kurhessen,

s. Schwarzburg: as Meiningen. 
Appendix 2: Live births in the larger states and Hanseatic cities, 1819-1900

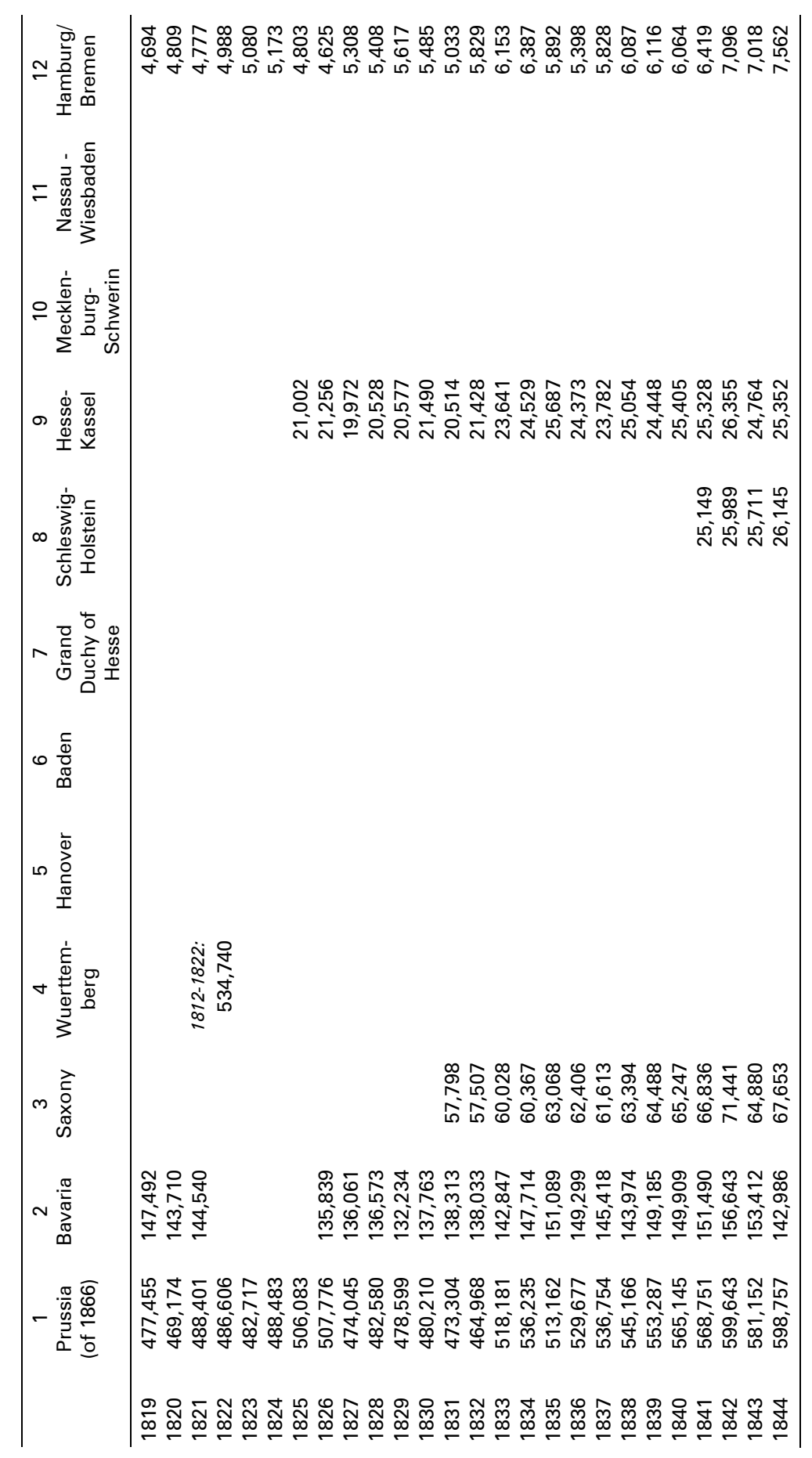




\section{Appendix 2 continuation}

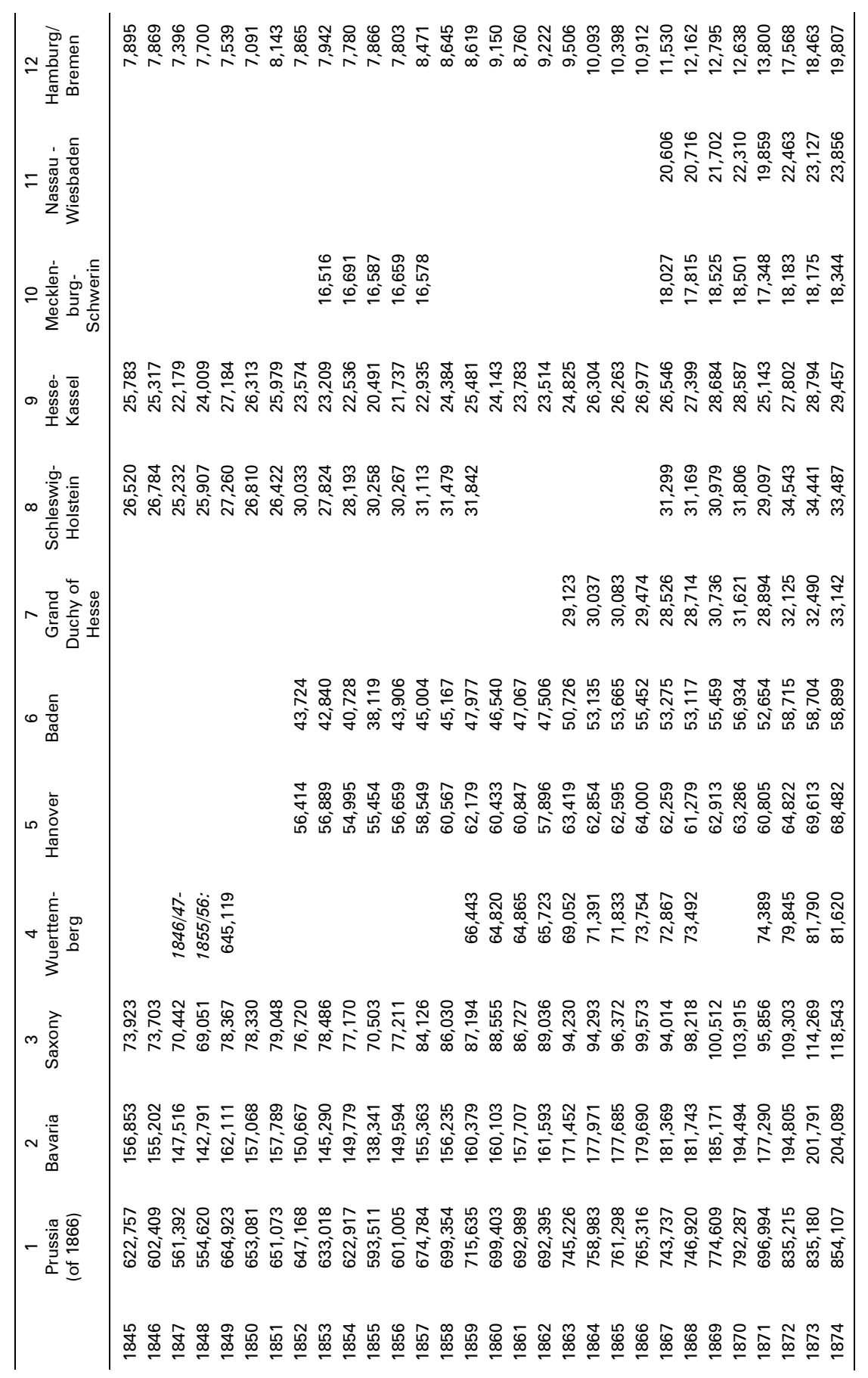




\section{Appendix 2 continuation}

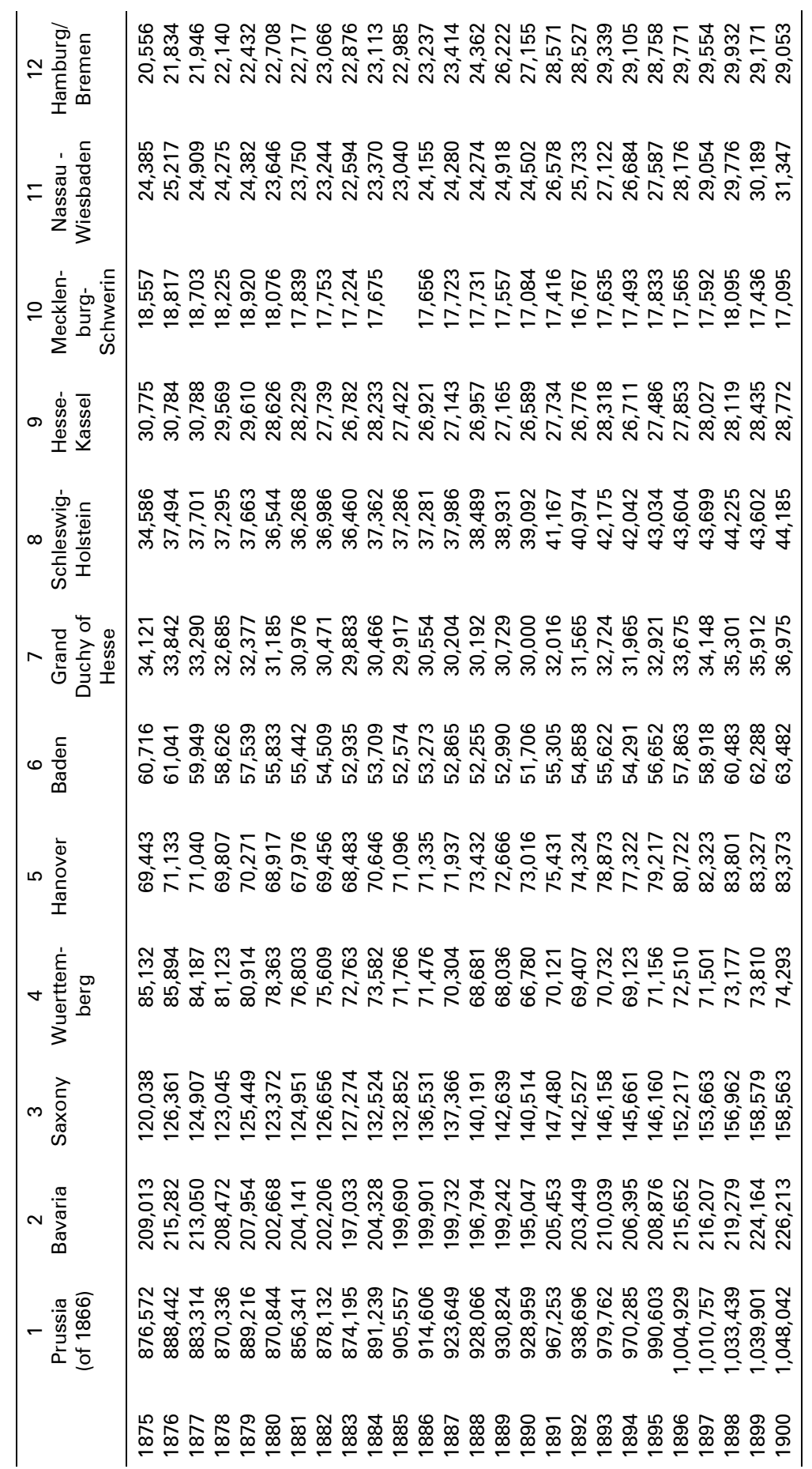


Appendix 3: Infant deaths in the larger states and Hanseatic cities, 1819-1900

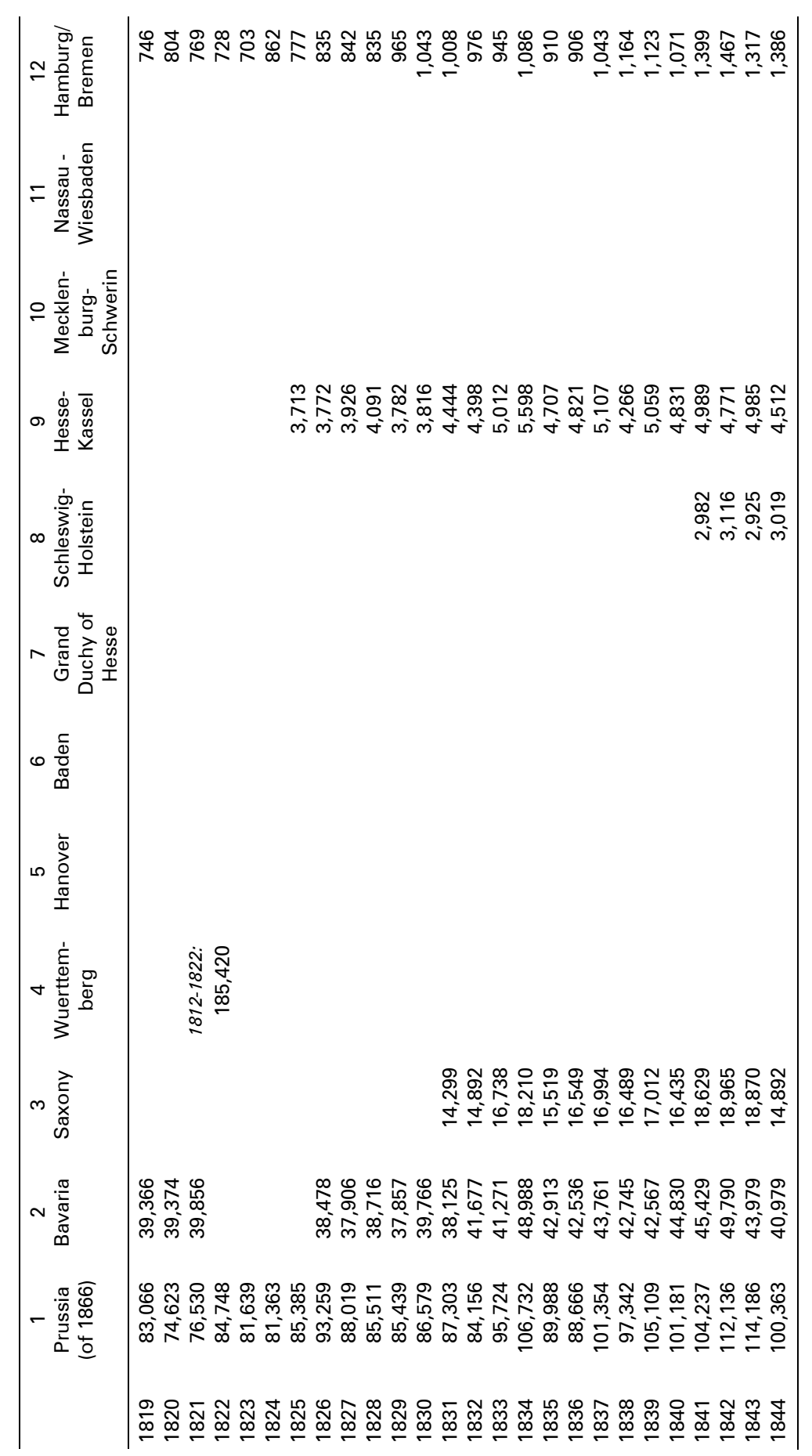




\section{Appendix 3 continuation}

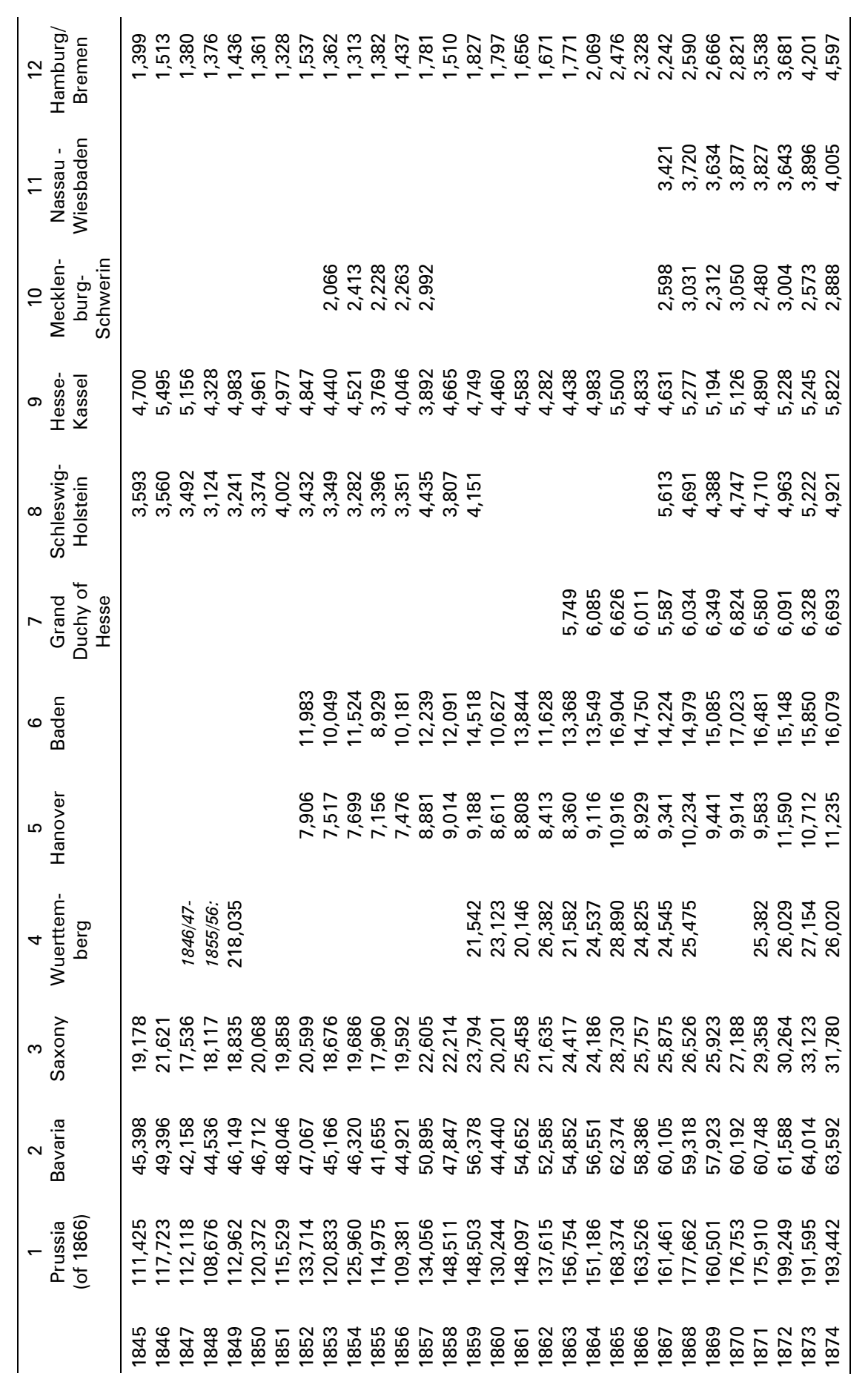




\section{Appendix 3 continuation}

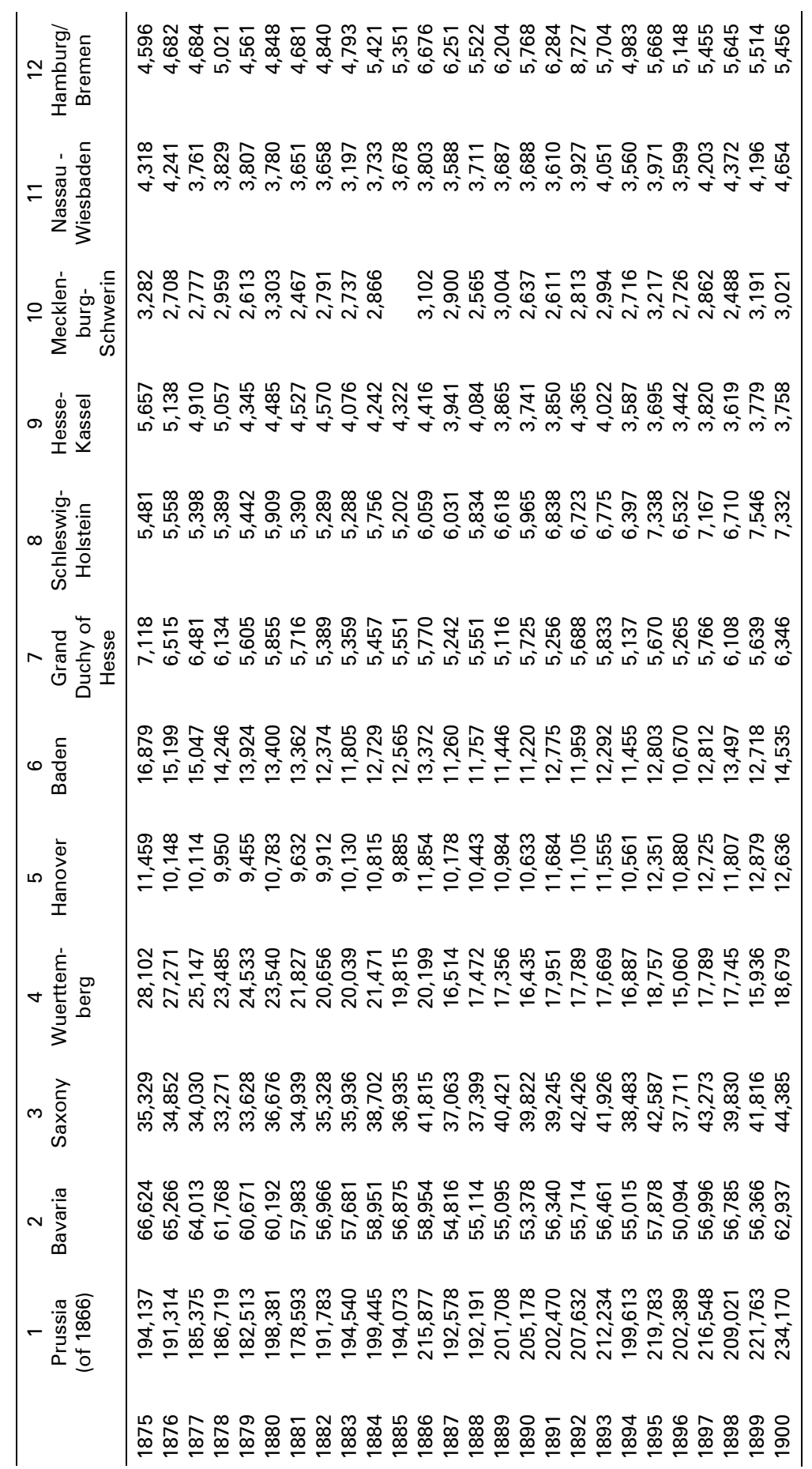




\section{Comparative Population Studies - Zeitschrift für Bevölkerungswissenschaft}

wWw.comparativepopulationstudies.de

ISSN: 1869-8980 (Print) - 1869-8999 (Internet)

Published by / Herausgegeben von

Prof. Dr. Norbert F. Schneider

Federal Institute for Population Research

D-65180 Wiesbaden / Germany

Managing Editor /

Verantwortlicher Redakteur

Frank Swiaczny

Editorial Assistant /

Redaktionsassistenz

Katrin Schiefer

Language \& Copy Editor (English) /

Lektorat \& Übersetzungen (englisch)

Amelie Franke

Copy Editor (German) /

Lektorat (deutsch)

Dr. Evelyn Grünheid

\section{Layout / Satz}

Beatriz Feiler-Fuchs

E-mail: cpos@destatis.de

\author{
Scientific Advisory Board / \\ Wissenschaftlicher Beirat \\ Jürgen Dorbritz (Wiesbaden) \\ Paul Gans (Mannheim) \\ Johannes Huinink (Bremen) \\ Marc Luy (Wien) \\ Clara H. Mulder (Groningen) \\ Notburga Ott (Bochum) \\ Peter Preisendörfer (Mainz)
}

\section{Board of Reviewers / Gutachterbeirat} Martin Abraham (Erlangen) Laura Bernardi (Lausanne) Hansjörg Bucher (Bonn) Claudia Diehl (Göttingen) Andreas Diekmann (Zürich) Gabriele Doblhammer-Reiter (Rostock) Henriette Engelhardt-Wölfler (Bamberg) E.-Jürgen Flöthmann (Bielefeld) Alexia Fürnkranz-Prskawetz (Wien) Beat Fux (Zürich) Joshua Goldstein (Rostock) Karsten Hank (Köln) Sonja Haug (Regensburg) Franz-Josef Kemper (Berlin) Michaela Kreyenfeld (Rostock) Aart C. Liefbroer (Den Haag) Kurt Lüscher (Konstanz) Dimiter Philipov (Wien) Tomáš Sobotka (Wien) Heike Trappe (Rostock) 